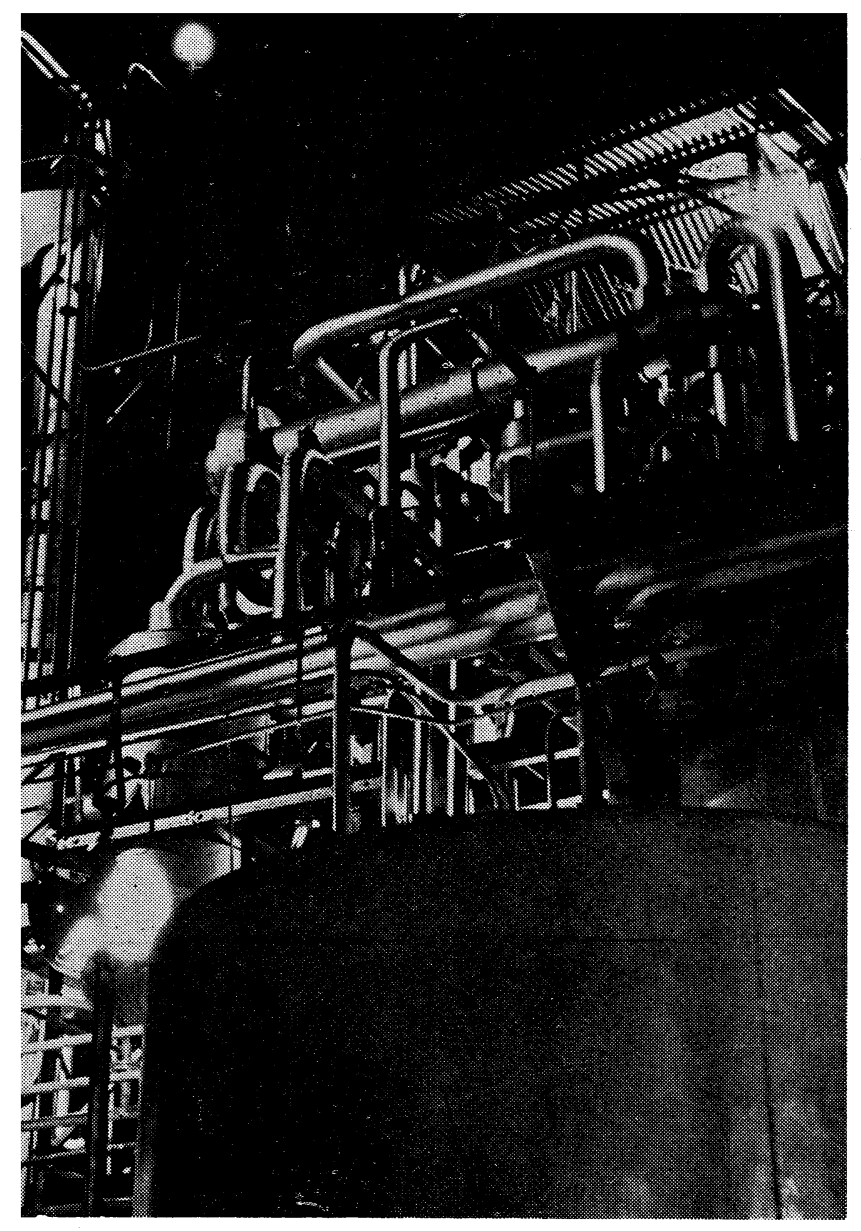

\title{
高分子工業展毞 (I)
}

一䁘睹工業を中心として一

\section{川 崎 京 市}

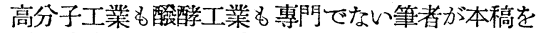
つづる資格はないが，辞退しきるととができずに昨 年 7 月末はるばる高野山まで出向いて，本題につい て話をしたゆきが办り上，またまた强いられて，そ の時の原稿を近りつつ, 本交をしたためる次第。読 者諸賢事情御賢察の上御吡正を賜わらんととを。
\end{abstract}

Dextran の製造工業をとり上げることにする。

Dextran 製造工業＼cjkstart蔒糖でも甜荣糖でもこれを搾 った汁はらっかりすると固まってこんにゃく狀になっ たり,ゲル狀になったりして,沪過を困難にすることは 昔から知られていた。これが何であるかを調べた結果

酸醏工業を中心として高分子工業を展望すると大体次 の三方向が考えられる。

（1）酸酵工業によって高分子物質を製造する工業

（2）高分子工業に用いられる酸㬝工業製品

(3) 酸猎工業に用いられる高分子工業製品

この中で (2) と（3）はむしろ高分子工業と酸㬝工業 の結びつきあるいは相互関係ともいうべきものであって (1) が本筋のものといえよう。

いずれにしてもこれらについて系統的に㒛說する余裕 も紙数もないので，これらの中で今日トピックになって いるもの二,三を拾い上げて解䜅を加えることとする。

\section{I 酘酵工業によって高分子物犋を製造する工業}

采統的に調べればいろいろな工業があろうし，また高 分子物質そのものの定義のいかんによっては現在この工 業に属していないと思っている工業も，この部頪にまと め上げることもできる。

例えば醴酩工業としてはその歷史も古く，またその篧 用も廣い潭素は, Polypeptide で立派な高分子物質である し, 後に触れる抗生物質中の Bacitracin \& Polypeptide で高分子物質であるから，これらの製造工業は本分類に 属するものであるが，ここでは本分類の代表として最近 日本でも新聞紙上その他に報道されている代用血漿

カット：2-エチルエキサノール製造裝置
それが葡萄糖の縮合物であることがわかって Dextrose Anhydride から Dextran なる名称が生れたものと思 われる。一方この搾汁について，これを加熱したり，石 炭酸を加えたりするとこの現象が起らないことから，こ れは微生物の作用で生產されるものであろうと考えて研 究した結果, 1878 年 Van Tieghem 氏が Dextran 生 座菌を発見し，それが緑藻の一種のじゅずも (Nostoc) に似たもので，色が白いところからこれを Leuconostoc と命名した。

その後 1944年 Sweden の Grönwall および Ingelman が Leuconostoc Mesenteroides といら菌で Dextran を製造し，これを代用血漿として使用して好 成績を收めてから急に注目されて來た。こうしてかって の有害菌が今日では人命救助に一役買うことになり, 蔗 糖から Dextran を製造するという新工業が生れたわけ である。

Dextran は葡萄糖が枝のある 鎖狀化合物の形に多数 結合して大きな分子となっている縮合物で，その点では 澱粉とか Cellulose とかに似ているが，その結合の位置

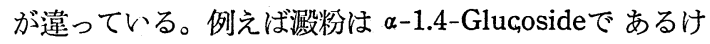
れども Dextran は $\alpha-1.6$-Glucoside である。もっとも 極めて少量は $2,3,4$ の位置で結合したものも混っては いるが，代用血漿用には 1.6 結合の直顉狀のものがよい 性能を示している。 


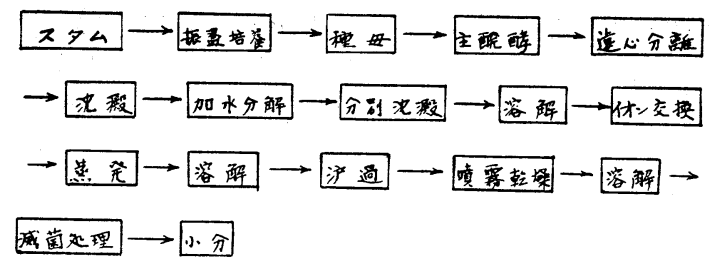

第 1 図 代用血漿デキストラン製造工程

その製造工程は第 1 図に示す通りで主嘸酵までは，條 件こそ違え，通常の船醉工業に見られる手段で菌を培養 して行って Dextranを生成させるもので,こうして生成 したDextran は非常に分子量が大きくかついろいろの大 きさの分子量のものが混在しているので，菌体を沪過分 離してその沪液からアルコール類で沈澱させたものを稀 塩酸などの鉱酸で加水分解して, 血嶈蛋白の平均分子量 75,000 に近い分子量にそろえる。こうして得られた Dextran 溶液をさらに分別沈激でもう一度分子量をそ ろえ, イオン交換樹脂で夾雜イオンを除去し, 蒸発濃縮

第 1 表 各國におけるデキストラン製造工業の現狀

\begin{tabular}{|c|c|c|c|c|c|c|}
\hline 國名 & 会 & 社 & 名 & \multicolumn{2}{|c|}{ 生崖能力 } & 備 \\
\hline イギリス & \multicolumn{3}{|c|}{ Graxo Laboratories } & \multicolumn{2}{|c|}{ 20,000パイント/月 } & \multirow{2}{*}{$\begin{array}{c}\text { 商品名Intradex } \\
\text { * }\end{array}$} \\
\hline " & \multirow{2}{*}{\multicolumn{3}{|c|}{ Phamacia Ltd. Uppsala }} & 不 & 洋 & \\
\hline スエーデン & & & & 150,000 & " & \multirow[b]{2}{*}{7} \\
\hline アメリカ & \multicolumn{3}{|c|}{ Commercial Solvents Corp. } & 100,000 & " & \\
\hline " & \multirow{2}{*}{\multicolumn{3}{|c|}{$\begin{array}{l}\text { R. K. Laros Corp. } \\
\text { J. T. Baker Chemical Corp. }\end{array}$}} & 30,000 & & \\
\hline "I & & & & 30,000 & " & \\
\hline " & \multicolumn{3}{|c|}{ Dextran Corp. Youkers } & 50,000 & " & * \\
\hline " & \multirow{2}{*}{\multicolumn{3}{|c|}{$\begin{array}{l}\text { Refined Suger \& Syr up Inc. } \\
\text { Graxo Laboratories }\end{array}$}} & 50,000 & " & $*$ \\
\hline 南アフリカ & & & & 20,000 & " & \\
\hline
\end{tabular}

* 印は Pharmacia Ltd. Uppsala と技術契約をしている会社。

して, さらに精製工程を経た後 $90^{\circ} \mathrm{C}$ で噴霧乾燥して結 晶をとり，これを小分けする。

現在 Dextran 製造工業は第1表に示したように各社 で行われているが最も多いのはアメリカである。この工 業は発祥の地が Sweden でその原特許は Swedenの Pharmacia Ltd in Uppsala が持っているので上表中 でもここと特許技術の使用契約を結んで行っているのが 多く，その手続を踏んでいないところでも Pharmacia Ltd からの提訴で係争中であるようである。

わが國でも数々の研究があり, 中でも台糖株式会社, 東大農学部，日本血液銀行などが手をつけているよう で，その中でも東大農学部の成果は名糖痤業株式会刑で 近く工業化されるように新聞は報じている。

高分子工業としてはこの Dextran に対抗するものに PVP (Polyvinyl Pyrolindon) がある。これは第二次 大戰中ドイッで製造しはじめて多くの人命を救ったとい うから代用血嶈としてはむしろこの方が時期が早い。今 日ではアメリカの General Aniline \& Film Corp. が
一番多く製造していると思われる。わが國でも阪大座研 の研究成果が小野藥品工業で工業化されるように聞いて いるが，昨年聞いたアメリカでの評判では，PVP を代 用血漿として用いるのにはまだ若干の問題が残っている ようである。

元來，平時において代用血將の問題を一番噴劍にとり 上げているのはアメリカである。これは人命の尊重から 人血をとることが人道に反するといらことばかりでな く，アメリカでは小兒麻痺が非常に多く，血液中に存す る小兒麻瘨の病原体（ビールスだという）の発見が非常 にむずかしいために，これの蒙延を恐れ，できるだけ人 血を用いないようにしたいといら念願からである。戰場 あるいは本時でもいろいろな事故による怪我などでは人 血を間に合わせる時間の余裕がない時が多いので，これ ら代用血漿が大きくクローズアップされてきた。またこ れらの代用血漿が出てきたので医学的にも新しいまたは 工夫されたいろいろの用途も生れてきつつあるようであ る。

\section{II 高分子工業に用いら れる醱䤃工業製品}

この部属には 2 通り考えられる。

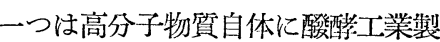
品が入り达んでしまう場合, すなわ ち高分子物質の骨格自体を酸酵工業 製品が一役買って形成する場合，も ら一つは高分子物質製品を製造する 場合に補助的に酸酵工業製品または それから誘導された製品を用いる場 合である。こう考えるとこの部瀬に

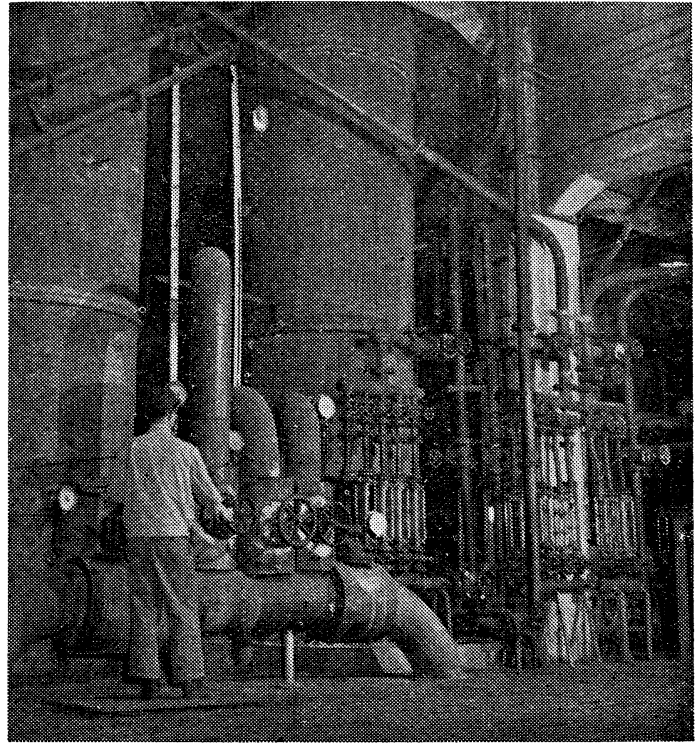

アロスパス式アルコール蒸溜機 


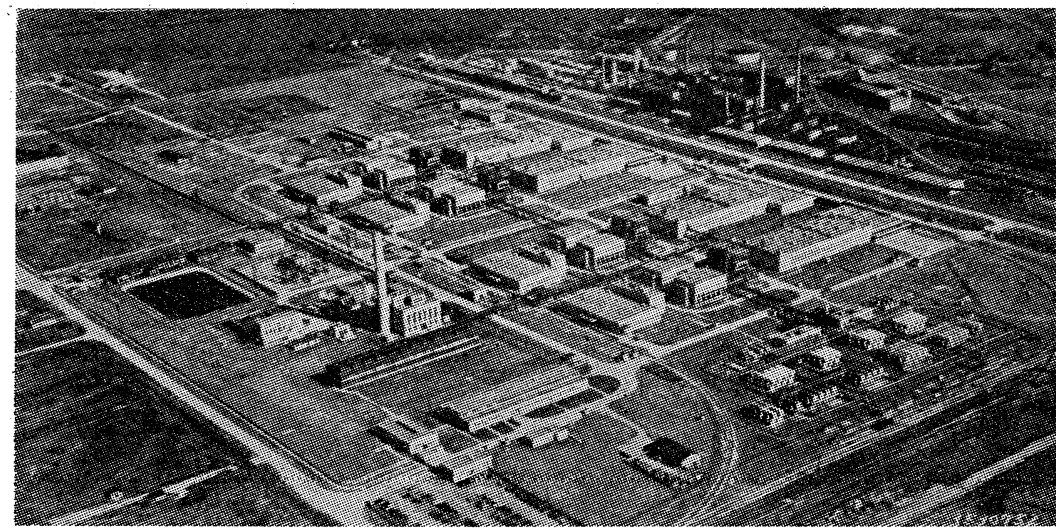

合成 ゴム製造工場全景

\section{（1）合成ゴム工業}

まず手許にある世界の生產統 計（共座圈を除く）を第 2 表に 揭げる。本表には 1953 年すな わち昭和 28 年の分は 1 月から 5 月までの数字しかない。また 本表に含まれている合成ゴムに はButadiene-Styrene Polymer すなわち ブナ S (米國の GRS.S-Type) という一番一般的に 用いられる合成ゴム，Butadi ene-Acryronitrile Polymer すなわち ブナ N（米國の GR-
はたくさんのものがある。例えば前者に属するものとし ては酘酵工業製品たる枸格酸から得られるある種のアル キッド, レジン, 醱酵工業によって得られるブタノール からブチルアルデヒドを製し，これとポリビニルアルコ ールとから得られるブチラール樹脂など数えられるし， 後者に属するものとしては同じく枸格酸からの可塑成な ども考えられるが, 本稿では前者の代表として合成ゴム 特に Butadiene-Styrene Polymer すなわちブナ S, 後 者の代表として可塑剤 DOP をとり上げてその展望を試 みる。

第 2 表 世界の合成ゴム生座量

\begin{tabular}{rc|rr|rr|rr|r}
\hline \hline 年 & 次 & アメリカ & カ ナ & ダ & 西 & 独 & 合 計 \\
\hline 1941 & 昭 16 & 8,114 & 10.5 & - & - & 69,361 & 89.5 & 77,475 \\
2 & 17 & 22,476 & 18.6 & - & - & 98,135 & 81.4 & 120,611 \\
3 & 18 & 231,767 & 66.2 & 2,522 & 7.2 & 115,754 & 33.2 & 350,043 \\
4 & 19 & 764,072 & 84.8 & 34,829 & 3.9 & 101,624 & 11.3 & 900,525 \\
5 & 20 & 820,352 & 94.6 & 45,717 & 7.3 & - & - & 866,069 \\
6 & 21 & 740,026 & 91.8 & 50,981 & 6.3 & 15,613 & 1.9 & 806,620 \\
7 & 22 & 508,702 & 90.9 & 42,393 & 7.6 & 8,224 & 1.5 & 559,319 \\
8 & 23 & 488,343 & 91.8 & 40,455 & 7.6 & 3,388 & 0.6 & 532,186 \\
9 & 24 & 393,689 & 89.4 & 46,642 & 10.6 & - & - & 440,331 \\
1950 & 25 & 476,184 & 89.1 & 58,440 & 10.9 & - & - & 534,624 \\
1 & 26 & 845,159 & 93.0 & 62,293 & 6.9 & 929 & 0.1 & 908,381 \\
2 & 27 & 798,566 & 90.9 & 74,272 & 8.5 & 4,931 & 0.6 & 877,769 \\
$(1 \sim 5)$ & $(1 \sim 5)$ & 386,114 & 91.4 & 33,944 & 8.0 & 2,344 & 0.6 & 422,402 \\
3 & 28 & 38,4 &
\end{tabular}

第 3 表 アメリカにおける合成ゴムの生座販賞量

\begin{tabular}{c|rr|rr|r|r}
\hline \hline 製 品名 & \multicolumn{2}{|c|}{ 生産量(單位1000 lbs) 販賣量(單位1000 lbs) 價格 (單位 \$1000) } & 單位\$/1b \\
\hline G R-S & $1,560,856$ & 77.9 & $1,406,196$ & 76.9 & 351,549 & 0.25 \\
G R-I & 166,000 & 8.3 & 155,958 & 8.5 & 32,361 & 0.21 \\
ブ ナ N & 34,352 & 1.7 & 32,268 & 1.8 & 16,659 & 0.52 \\
ネオプレン & 131,952 & 6.6 & 124,867 & 6.8 & 47,449 & 0.38 \\
ポリビニル & 90,054 & 4.5 & 89,391 & 4.9 & 53,616 & 0.60 \\
そ の 他 & 19,921 & 1.0 & 19,089 & 1.1 & 13,146 & 0.69 \\
計 & $2,003,135$ & 100.0 & $1,827,769$ & 100.0 & 514,780 & 0.28 \\
\hline
\end{tabular}

A，N-Type）という耐油性，耐藥品性の强い合成ゴム， Isobutylene-Isoprene Polymer すなわち ブチルゴム (米國の GR-I.) といら空氣の透過率の非常に小さい從 って自動車タイヤの中袋によく使われる合成ゴム，Monovynyl Acetylene または Chloroprene Polymer (米 國の GR-M, Neoprene) といら合成ゴムを含んでいて, Thiokol は含まれていない。

第 2 表を見ると第二次大戰が合成ゴム工業を発達させ るためにいかに役立ったかがわかると同時に，石炭から の化学を主としたドイッと石油からの化学を主としたア
(單位 トン)

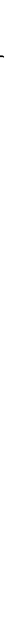
メリカとの間の角逐がはっきりと見てと れる。

\section{そこでこれら各國の狀況を調べて見よ う。}

アメリカ合衆國 まずその品種別の 生牵量を見ると第 3 表のようである。本 表を見ればわかるように大牛は GR-S すなわちブナ S である。ブナ S は天然 ゴムに一番近い性質を持ち一番やすいゴ ムなので，今まで天然ゴムを使っていた ところはほとんど使らことができるから である。單價の闌を見ると GR-S は 25 セントでこれよりもやすい GR-I があ り，その單價は 21 セントであるが，こ れはその性質上天然ゴムを使っているど の部分にも使うということができない。 ただ空氣の透過率が非常に少ないのでア メリカの中袋はほとんどこれによってお きかえられているようである。

次にこれらの生崖に当っている会靕を 調べて見ると第 4 表のようである。第 4 表には伸長率 $150 \%$ 以上で比較的早く 復原するものを合成ゴムとしてその製造 会跍を列挙したものである。

アメリカの合成ゴム工業は政府事業の 
一つで，ブナ S とブチルゴムはそ の全部が政府所有の工場で政府が経 営しており，その操業を各合成ゴム 会社に行わせて, 合成ゴム 1 ポンド 当り幾何かの操業手数料を拂ってい る。ところが昨年 6 月下院， 7 月上 院の議決を経て 8 月大統領が署名し て，本年すなわち 1955 年 1 月まで にこれらの工場を全部民間会社佛 い下げることにきめられた。これら の工場の能力を調べると第 5 表の通 りである。

カナダ カナダの合成ゴム工業 はアメリカの合成ゴム計画を達成す るための一環として着手せられたも ので, 何から何までアメリカの援助 をもってカナダ政府が全額出資して Polymer Corp. という会社をつく って 1942 年 Sarnia に工場を建設 したのがはじめで, その最近の生產 実績注第 6 表のようである。第 6 表 と第 2 表に若干のくいちがいがある のは第 2 表は曆年で表わし, 第 6 表 は 4 月から 3 月までの年度で表わし てあり，特に 1952 年は 1952 年 4 月から 12 月までの 9 カ月間の統計 であるからである。

アメリカは各工程別に会社が別で

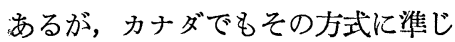
ている。その能力および操業担当会 駀を調べて見ると第 7 表の通りであ る。

カナダのブタジェンはブチレンか ら製造するもので Standerd Oil Developement Co. の系統である Imperial Oil Co. の子会社である Sunt Clair Processing Corp. が Oil Refining から得ているむのである。

ドイッ ドイッは合成ゴム発祥の地であり, アメリ カのブナ $\mathrm{S}$ は最初ドイッの特許を買ってはじめられた ものである。第二次大戰中は I. G. で第 2 表に見られる 樋り世界第 1 位の生產量を誇っていたが, 戰後東西に分 割され，その中の大きな工場は東独側にあり，西独では 第 8 表のように制限されている。

この外に西独には年間 3,000 トンあまりのネオプレン の需要がありその計画を持っているともいわれている。

ドイッでは後述のように Butadiene をいわゆる4 段 法でアセテレンから製造しており，そのコストが高く，
第 4 表 アメリカにおけす合成ゴム製造会社

\begin{tabular}{|c|c|}
\hline 製 品 種 類 & 社 \\
\hline $\begin{array}{l}\mathrm{G} \mathrm{R}-\mathrm{S} \\
\text { すなわち } \\
\text { ブ ナ } \mathrm{S}\end{array}$ & $\begin{array}{l}\text { Copolymer Corp. } \\
\text { Firestone Tire \& Rubber Co. } \\
\text { B. F. Goodrich Co (B. F. Goodrich Chemical Co. Div.) } \\
\text { Goodyear Tire \& Rubber Co. (Goodyear Synthetic } \\
\text { Rubber Corp. Div.) } \\
\text { General Tire \& Rubber Co. } \\
\text { Kentucky Synthetic Rubber Corp. } \\
\text { U. S. Rubber Co. } \\
\text { Midland Synthetic Rubber Co. } \\
\text { Philips Petrolum Co. }\end{array}$ \\
\hline $\begin{array}{l}\mathrm{G} \quad \mathrm{R}-\mathrm{I} \\
\text { すなわちブチルゴム }\end{array}$ & $\begin{array}{l}\text { Humble Oil \& Refining Co. } \\
\text { Esso Standerd Oil Co. }\end{array}$ \\
\hline $\begin{array}{l}\text { ブ ナ } \mathrm{N} \\
\text { すなわち } \\
\mathrm{G} \mathrm{R}-\mathrm{A}\end{array}$ & $\begin{array}{l}\text { Fireston Tire \& Rubber Co. } \\
\text { Heresite \& Chemical Corp. } \\
\text { U. S. Rubber Co. (Naugatuck Chemical Div.) } \\
\text { Goodyear Tire \& Rubber Co. (Goodyear Synthetic } \\
\text { Rubber Corp. Div.) } \\
\text { B. F. Goodrich Co. (B. F. Goodrich Chemical Co. Div.) }\end{array}$ \\
\hline ネオプレン & E. I. Du Pont De Nemours \& Co. Inc. \\
\hline ポリビ $=$ ル & $\begin{array}{l}\text { B. F. Goodrich Co. (B. F. Goodrich Chemical Co. Div.) } \\
\text { Monsanto Chemical Co. } \\
\text { Union Carbide \& Carbon_Corp. (Carbide \& Carbon } \\
\text { Chemical Corp. Div.) }\end{array}$ \\
\hline Polyacrylate & B. F. Goodrich Co. (B. F. Goodrich Chemical Co. Div.) \\
\hline Thiokol & Thiokol Corp. \\
\hline Poly-butadiene & $\begin{array}{l}\text { Goodyear Tire \& Rubber Co. (Goodyear Synthetic } \\
\text { Rubber Corp. Div.) }\end{array}$ \\
\hline $\begin{array}{l}\text { Poly-butadiene } \\
\text {-methylmetha } \\
\text {-crylate }\end{array}$ & U. S. Rubber Co. (Naugatuck Chemical Div.) \\
\hline SiliconeElastmer & $\begin{array}{l}\text { Dow Chemical Co. } \\
\text { General Electric Co. (Chemical Dept.) }\end{array}$ \\
\hline Cyclo-Rubber & $\begin{array}{l}\text { Goodyear Tire \& Rubber Co. (Goodyear Synthetic } \\
\text { Rubber Corp. Div.) }\end{array}$ \\
\hline Parlon & Herucles Powder Co. \\
\hline
\end{tabular}

アメリカの合成ゴムと競爭することができないが，ゴム 製品業者が天然ゴムを使用するに應じて，若干の金をプ 一ルし，これを合成ゴム製造業者の生產量に應じて，合 成ゴム製造業者に戻し，天然ゴムと合成ゴムとの價格の 調整を図り，合成ゴムの製造を獎励している。ブナS 第 8 表のように 6,000 トンの能力になっているが, 装置 は 30,000 トン分を持っており, 占領軍の許可を待って いる狀態である。

その他の國 フランスはアルコールからブタジェン をつくりそれからブナ $\mathrm{S}$ を製造する企てを持っており， そのための委員会を 2 回も持ったが，その植民地に天然 


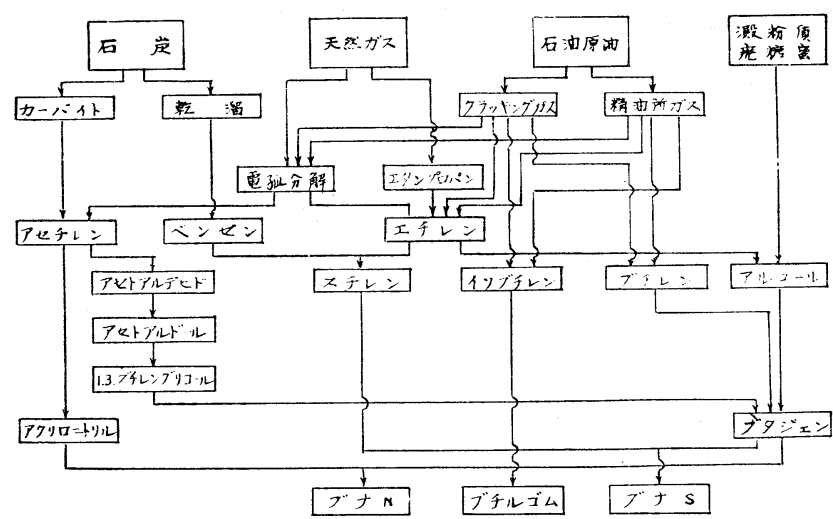

第 2 図 ブナ $\mathrm{S}$ ，ブナ $\mathrm{N}$ ，ブチルゴムの製法

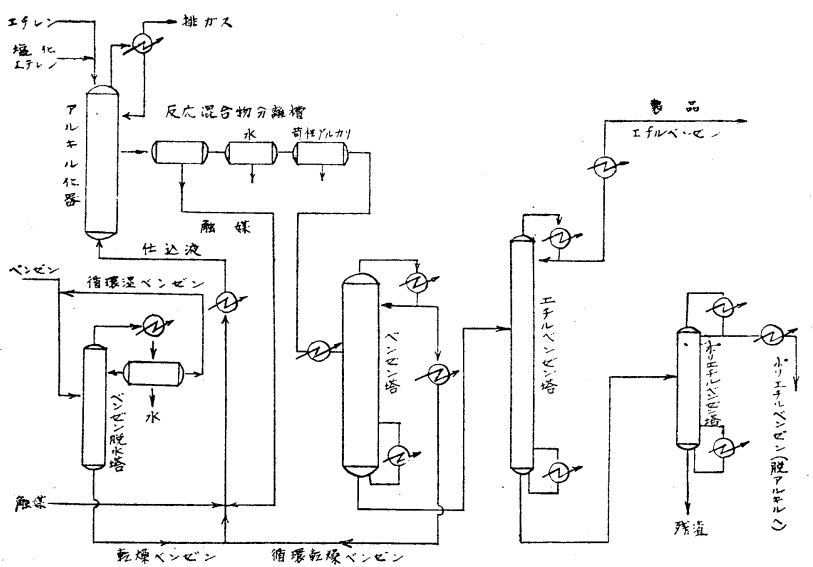

第 3 図エチルベンゼン

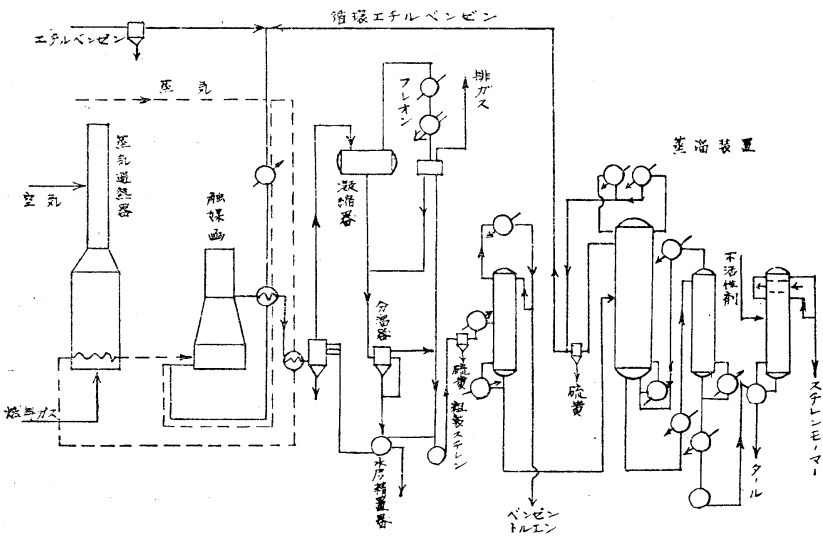

第 4 図ス チレン

ゴムを童出するところがあること，その業者がフランス 本國內におること, 諧備の建設費が蒿むことなどでまだ 実現していない。しかしこれとは別に化学工業会社でブ チルゴム生產の企てがあるようにも聞いている。

イギリスでも丵だけはっきりはしないがブテルゴムの 生産その他の企てがあると聞いている。

日本では一昨年來民間任委員会を持って目下檢討中で あるが，このことについては後で触れる。
以上大体合成ゴム工業の現狀を記述したが，こ れら合成ゴムの中で噟くゴムとして用いられるブ ナ $\mathrm{S}$, ブナ $\mathrm{N}$, ブチルゴムの製造についてその方

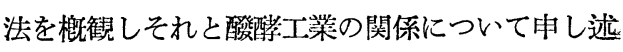
べる。

合成ゴムの製造法と醱酵工業＼cjkstart合成ゴムの直 接の原料は Butadiene Styrene, Acryronitrile, Butylene であって,アメリカではブタジェンをア ルコールまたはブチレンから，スチレンをエチレ ンとベンゾールから，アクリロニトリルを天然ガ スからのアセチレンと, 同じく天然ガスからの毒 酸から製造しており，カナダではブタジェンをブ チレンからつくり，他はアメリカと同樣な方法を 探用し，ドイッでは電弧分解でっくったアセテレ ンから 4 段法でブタジェンをつくり，同じく電弧 分解でアセチレンと共に得られるエチレンからス チレンをつくって合成ゴムをつくっている。これ らの関係を図示すると第 2 図の通りとなる。これ らの各工程はアルコールからブタジェンは本誌第, 3 谷第 1 号第 21 ページの第 2 図, ブチレンから ブタジェンは同じく第 23 ページ第 4 図と第 5 図, スチレンは本稿第 3 図と第 4 図, アクリロニトリ ルは第 5 図, イソブチレン抽出は第 6 図, ブナS およびブナ $\mathrm{N}$ の共重合裝置は本誌第 3 卷第 1 号 第 24 ページの第 6 図，ブチルゴムは同じく第 25 ページ第 7 図に示した略図の通りであるが，紙数、 の関係もあり詳細な說明は省略する。

第 2 四からむわかるようにこの合成ゴム製造に 醴醭工業が一役買っている。すなわちブタジェン を酸䣼アルコールから製造するので, 現在ではア メリカのUnion Carbide and Carbon Corp. が最 高峰の技術を持っており, ぞの会社もこの会社の 技術を買っている。その反應は第 7 図の反應を利 用するものである。この際の收量関係法本誌第 3 歓第 1 号第 21 ページ第 1 表に示してある。これ に対して一般に用いられている精油所ガスからの ブタジェンは同じ第 22 ページ第 3 図に示すよ うな收量関係があり，從ってこの方法でブタジェ. ン 1 トンを製造すると同じく第 22 ページ第 2 表 に示されてあるような副產物が得られる。という いい方は少し無理で実はブタジェンそのものが副產物で あるといらいい方の方がよいのではなかろうか。これに よるとブタジェンは原油汇対し $0.9 \%$ を得ることになり 1 トンのブタジェンを製造するためには原油 800 バーレ ルを処理しなければならない。

アメリカではアルコールからつくるブタジェンはュス ト高でブチレンが豐富である間は，すなわちブチレンが 高級航空機燃料その他重要な方面に使ってなおあまり女 


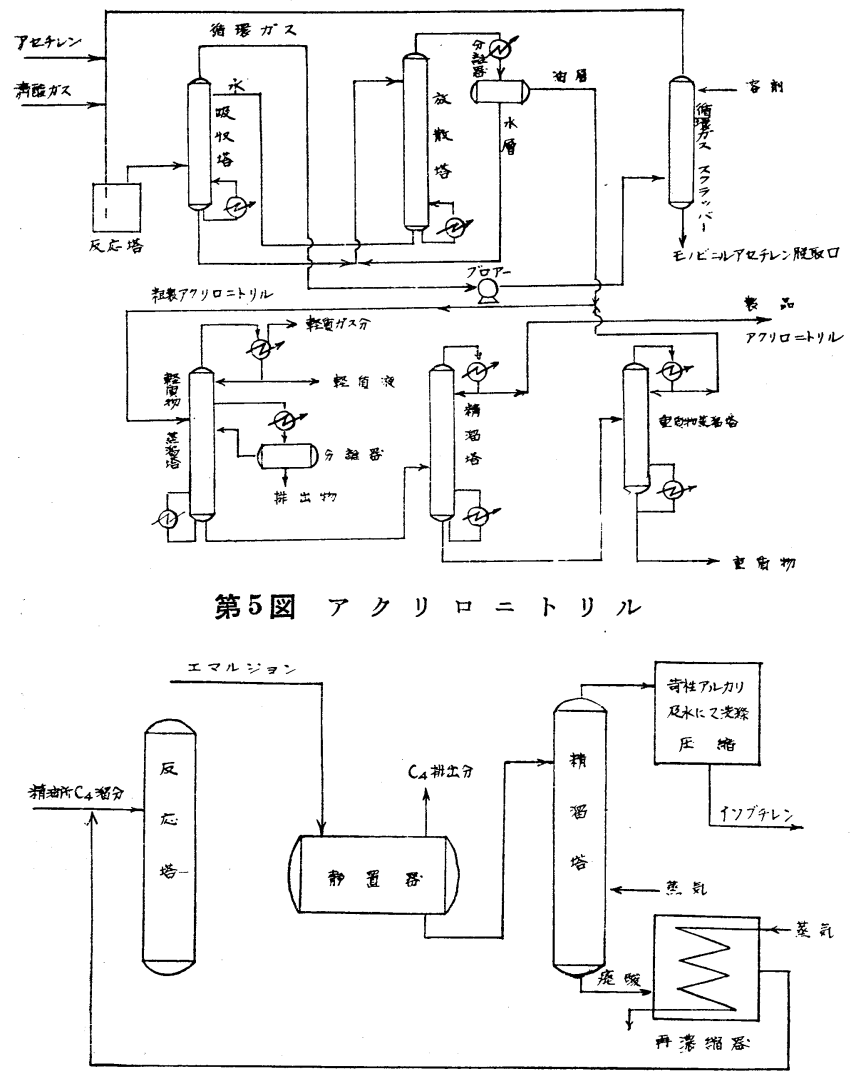

第6図イソブチレン抽出

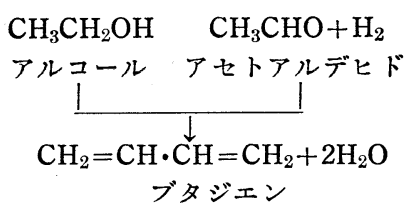

第7図 アルュールからブタジェン

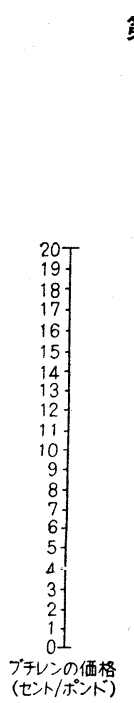

第9図 ブチレンの脫水素によるブ タジェンの直接原價（減僨償却費 および研究費を除く)

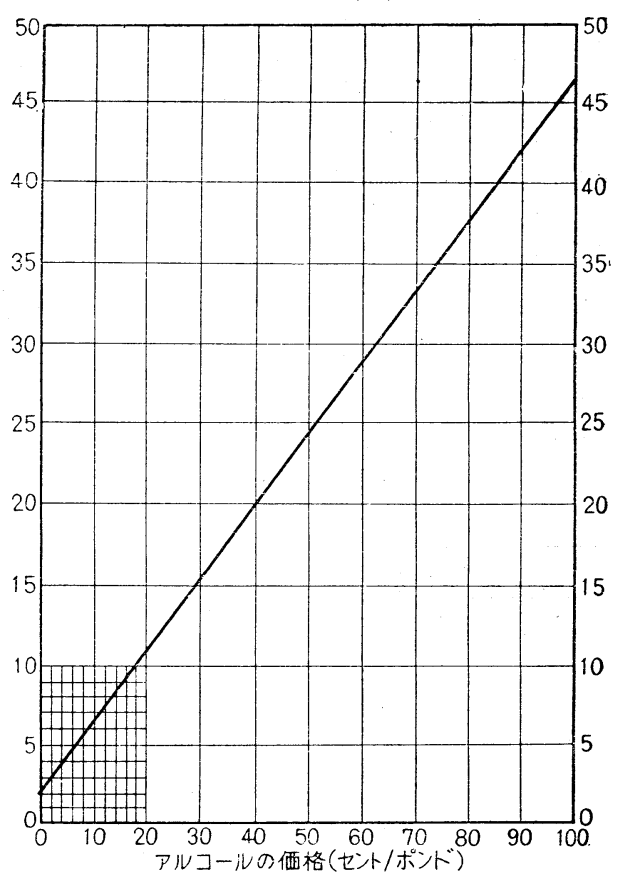

第 8 図アルコール法によるブタジェンの推定值 接原價（減價償却費および研究費を除く） (アルコール 1 ガロンよりブタジェン 2.29 ポンドを得るものとする)

る間は,アルコールからのブタジェンを休止させ， ブチレンがたりなくなるとアルコールからのブタ ジェン工場を動かすことにしている。これらのコストの 関係を表示すると第 9 表となり，グラフまたはノモグラ フで示すと第 8 図，第 9 図となり，第 10 困はスチレン

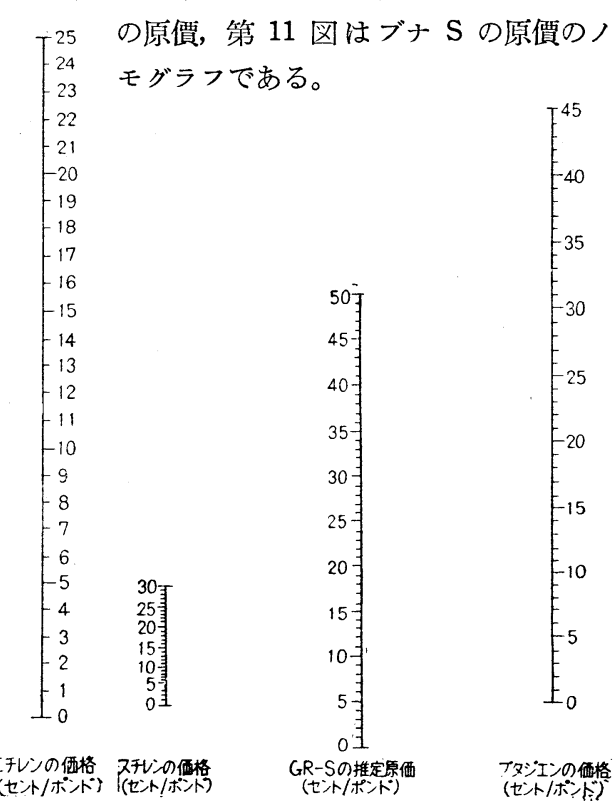

第11図 ブタジェンとスチレンの價 格による GR-S の推定直接原價 （減價償却費および研究費を除く） 
第 5 表 アメリカ政府所有合成ゴム工場

\begin{tabular}{|c|c|c|}
\hline 操 業 会 社 & 工 場 所 在 地 & 年產能力 \\
\hline \multicolumn{3}{|l|}{ (1) 石油よりのブタジェン工場 } \\
\hline $\begin{array}{l}\text { Cities Service Refining Corp. } \\
\text { Copolymer Corp. } \\
\text { Humble Oil \& Refining Co. } \\
\text { Neches Butane Products Co. } \\
\text { Philips Chemical Co. } \\
\text { Sinclair Rubber Inc. } \\
\text { Shell Chemical Corp. } \\
\text { Standerd Oil Co. of Calif. } \\
\text { 計 }\end{array}$ & $\begin{array}{l}\text { Lake Charles, La. } \\
\text { Baton Rouge, La. } \\
\text { Baytown, Texas. } \\
\text { Port Neches, Texas. } \\
\text { Borger, Texas. } \\
\text { Houston, Texas. } \\
\text { Los Angels, Calif. } \\
\text { E1 Segundo, Calif. }\end{array}$ & $\begin{array}{c}60,000 \mathrm{~S} . \mathrm{T} . \\
23,000 \\
49,000 \\
197,000 \\
71,200 \\
78,000 \\
61,000 \\
- \\
539,200\end{array}$ \\
\hline \multicolumn{3}{|c|}{ (2) アルニールよりのブタジェン工場 } \\
\hline $\begin{array}{l}\text { Union Carbide \& Carbon Corp. } \\
\text { Koppers Co. Inc. } \\
\text { 計 }\end{array}$ & $\begin{array}{l}\text { Louisville, Ky. } \\
\text { Kobuta, } \mathrm{Pa} .\end{array}$ & $\begin{array}{l}87,000 \mathrm{~S} . \mathrm{T} \\
128,000 \\
215,000\end{array}$ \\
\hline \multicolumn{3}{|l|}{ （3） GR-S 工場 } \\
\hline $\begin{array}{l}\text { Copolymer Corp. } \\
\text { Firestone Tire \& Rubber Co. } \\
\text { " } \\
\text { General Tire \& Rubber Co. } \\
\text { B. F. Goodrich Co. } \\
\text { " } \\
\text { Goodyear Synthetic Rubber Corp. } \\
\text { " } \\
\text { Kentucky Synthetic Rubber Corp. } \\
\text { Midland Rubber Co. } \\
\text { Philips Chemical Co. } \\
\text { U.S. Rubber Co } \\
\text { " c }\end{array}$ & $\begin{array}{l}\text { Baton Rouge, La. } \\
\text { Akron, Ohio. } \\
\text { Lake Charles, La. } \\
\text { Baytown, Texas. } \\
\text { Port Neches, Texas. } \\
\text { Institute, W. Va. } \\
\text { Akron, Ohio. } \\
\text { Houston, Ohio. } \\
\text { Louisville, Ky. } \\
\text { Los Angels, Galif. }\end{array}$ & $\begin{array}{c}49,000 \mathrm{~L} . \mathrm{T} . \\
30,000 \\
99,600 \\
44,000 \\
90,000 \\
122,000 \\
15,200 \\
99,600 \\
44,000 \\
89,000 \\
66,000 \\
22,200 \\
89,400 \\
860,000\end{array}$ \\
\hline
\end{tabular}

（4）ブチルゴムすなわち GR-I 工場

\begin{tabular}{|c|c|c|c|c|c|c|}
\hline \multicolumn{4}{|c|}{$\begin{array}{c}\text { Humble Oil \& Refining Co. } \\
\text { Esso Standerd Oil \& Co. } \\
\text { 計 }\end{array}$} & \multicolumn{2}{|c|}{$\begin{array}{l}\text { Baytown, Texas. } \\
\text { Baton Rouge, La. }\end{array}$} & $\begin{array}{l}43,000 \mathrm{~S} . \mathrm{T} \\
47,000 \\
90,000\end{array}$ \\
\hline \multicolumn{7}{|c|}{ 第 6 表 カナダにお㧍る合成ゴム生座狀況 } \\
\hline 種 & \multicolumn{2}{|l|}{ 類 } & \multicolumn{2}{|c|}{1951 年 } & \multicolumn{2}{|c|}{1952 年 (9 カ月) } \\
\hline ブ & ナ & S & \multicolumn{2}{|c|}{51,071} & \multicolumn{2}{|c|}{41,384} \\
\hline \multirow[t]{2}{*}{ ブ チ } & \multirow{2}{*}{\multicolumn{2}{|c|}{$\begin{array}{l}\text { ル ゴ ム } \\
\text { 計 }\end{array}$}} & \multicolumn{2}{|c|}{15,312} & \multicolumn{2}{|c|}{12,679} \\
\hline & & & \multicolumn{2}{|c|}{66,383} & \multicolumn{2}{|c|}{54,063} \\
\hline
\end{tabular}

第 7 表 カナダの合成ゴム工場の能力

\begin{tabular}{|c|c|c|}
\hline 製 品 名 & 㷏 名 & $\begin{array}{c}\text { 年挙能力 } \\
\text { (トン) }\end{array}$ \\
\hline ナ & Canada Synthetic Rubber Corp. & 30,000 \\
\hline ブチルゴム & Sunt Clair Processing Corp. & 7,000 \\
\hline ブタジェン & " & 30,000 \\
\hline ステレン & Dow Chemical Co. & 10,000 \\
\hline
\end{tabular}

現在のブナ $\mathrm{S}$ は政府からの拂い下げ價格 は 1 ポンド 23 セントであるが，これにはア ルコールからのブタジェンは休止中であるの で入っていない。

日本における合成ゴム委員会 合成ゴム 委員会と簡單に畫いたが正確には合成ゴム製 造株式会社創立準備委員会という長い名前で ある。委員長は高橋龍太郎氏で一昨年組織さ れ，メンバーはアルコール製造策者およびゴ 么製品製造業者の有志とその他の人々で，い ろいろ檢討を加えた結果海外合成ゴム工栄調 查團を派遣して調查した結果に基づいて計画 しているが，まだ委員会そのものの結論は出 ていない。筆者は幸いにその調查團の 1 員に 加えられて檢討する機会を與えられたので目 下問題になっている楛点についてその模樣を 記述し私見を加えてみる。

わが國で合成ゴムを製造するとなるとその 原料として何を撰ぶかが第一の問題になる。 すなわちブタジェンの製造をとってもこれを アルコールからスタートするか不油からスタ ートするかが問題になる。管者が本紙第 3 卷 第 1 号 22 ページ右欄後牛に簡單な計算を行 ったように石油からスタートするとすれば非 常に大量のものを用意しなければならぬ。残 りは廃物になるわけでないが日本で果してそ れらのものの市場があるであろらか。なかな かの問題である。一方アルュールはという と,アルコール躌酵工業の設備は全國に政府 所有の工場および民間工場が数多く散在して いてその能力は第 10 表に示す通りである。 これらがどれだけ稼動しているかといらと第 11 表に示した生產実績でその稼動率は 28 年 度で $24 \%$ に過ぎない。もっとも第 10 表の 能力の中で若干は清酒醪添加用アルコールを 生產している向もあるので実際の稼動率はこ れよりも大分上椢ることになる。しかし合成 ゴム 30,000 トンに必要なブタジェンの出発 原料としてのアルコールは 80,000 キロリッ トル,生甘諸にして, 全生産額の約 $10 \% 1$ 億 5 千万貫でたりるのであるからまず問題はな い。そこで閴はュストである。アルコール でやるとどうしても高いから何かコストの引 き下げ策はないものかといろいろ檢討してい るが, 廃糖蜜の醱酵でアルコールをつくれば どうかといらに 1 キロリットル 55,000 冈にす ることはできる。そうすると合成ゴムは kg 242 円, ポンド 110 円となる。ただ今天然ゴム 


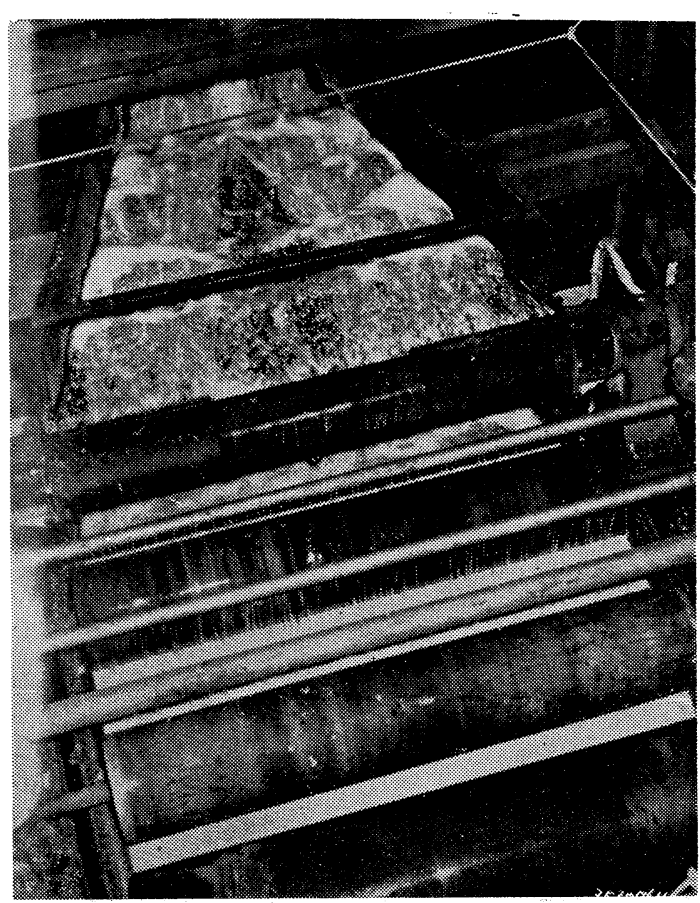

合成ゴム製造工程中重合物の洗滌
第 10 表 日本におけるアルコール工場およびその能力

(キロリットル/年)

\begin{tabular}{|c|c|c|c|}
\hline 経 営 & 別 & 会社名または工場名 & 能 力 \\
\hline \multirow[t]{10}{*}{ 官 } & \multirow[t]{10}{*}{ 営 } & 千 葉 工 & 3,600 \\
\hline & & 石 岡 工 & 3,600 \\
\hline & & 磐 田 工 & 3,600 \\
\hline & & 近 永工場 & 7,200 \\
\hline & & 肥 後大津 工 場 & 3,600 \\
\hline & & 相 知 工 場 & 3,600 \\
\hline & & 出 水 工 場 & 10,800 \\
\hline & & 鹿 屋 工 場 & 3,600 \\
\hline & & 小 林 工 埸 & 3,600 \\
\hline & & 小 & 43,200 \\
\hline \multirow[t]{7}{*}{ 民 } & \multirow[t]{7}{*}{ 営 } & 國 策 パルフ & 1,440 \\
\hline & & $\begin{array}{lll}\text { 王 } & \text { 製 } & \text { 組 }\end{array}$ & 1,440 \\
\hline & & 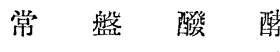 & 360 \\
\hline & & 酒 & 28,800 \\
\hline & & 三 樂 酒 造 & 13,200 \\
\hline & & 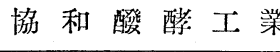 & 24,000 \\
\hline & & 計 & 69,240 \\
\hline & 総 & 計 & 112,440 \\
\hline
\end{tabular}

第 8 表 ドイッの合成ゴム工場の能力

\begin{tabular}{ccc|c|c}
\hline \hline 種 & 類 & \multicolumn{1}{|c|}{ 会 } & \multicolumn{1}{c|}{ 社: 名 } & 年座能力(トン) \\
\hline ブ & ナ & $\mathrm{S}$ & Chemische Werke Hüls & 6,000 \\
ブ & ナ & $\mathrm{N}$ & Farbenfabriken Bayer & 1,800 \\
\hline
\end{tabular}

第 9 表 ブタジェンおよび GR-S の原價

(GR-S 1 ポンド当りの原價，單位セント，償却費を含まず)

\begin{tabular}{|c|c|c|c|c|}
\hline & $\begin{array}{l}\text { ブタジ } \\
\text { エン }\end{array}$ & $\begin{array}{l}\text { スチ } \\
\text { レン }\end{array}$ & $\begin{array}{l}\text { 重 拿 } \\
\text { 加工費 }\end{array}$ & (GRS 䚺原傊) \\
\hline 1. 政府工場平均原供 (1950) & 23.5 & 2.2 & 5.0 & 30.7 \\
\hline 2. 現在考えられる最高能率工場 & 4.5 & 1.4 & 4.6 & 10.9 \\
\hline
\end{tabular}

3. アルコール法により可能と考えられる原偪

(スチレンは 1 ポンド 5 セントとする)

\begin{tabular}{|c|c|c|c|c|c|c|c|}
\hline & 26.2 & 1.1 & 4.5 & 31.8 \\
\hline \multicolumn{4}{|c|}{ アルコール 1 ガロン 90 セントの場合 } & 15.2 & 1.1 & 4.5 & 20.8 \\
\hline "I & $" \prime$ & 30 & "I & 9.8 & 1.1 & 4.5 & 15.4 \\
\hline$\prime \prime$ & $" \prime$ & 25 & "I & 8.5 & 1.1 & 4.5 & 14.1 \\
\hline " & $" \prime$ & 20 & " & 7.2 & 1.1 & 4.5 & 12.8 \\
\hline$\prime \prime$ & " & 15 & " & 5.8 & 1.1 & 4.5 & 11.4 \\
\hline
\end{tabular}

4. 石油法により可能と考えられる原價

(スチレンは 1 ポンド 5 セントとする)

\begin{tabular}{|c|c|c|c|c|c|c|c|}
\hline \multicolumn{4}{|c|}{ スチレン 1 ガロン 10 セントの場合 } & 5.1 & 1.1 & 4.5 & 10.7 \\
\hline$\prime \prime$ & $\prime \prime$ & 8 & $\prime \prime$ & 4.6 & 1.1 & 4.5 & 10.2 \\
\hline$\prime \prime$ & $\prime \prime$ & 6 & $\prime \prime$ & 4.2 & 1.1 & 4.5 & 9.8 \\
\hline$\prime \prime$. & $\prime \prime$ & 4 & $\prime \prime$ & 3.8 & 1.1 & 4.5 & 9.4 \\
\hline
\end{tabular}


る率を $25.7 \%$ とおさえる)。ただし出発が廃糖蜜から 考えているから甘諸の問題をどうするかという問題が残 っている。もし甘藷からのアルコールということを固執 することになれば，外貨節約といら大目的のためにあら ゆる方面から協力を願ってアルコール專賣規則に若下の 手を入れれば解決するのでなからうか。

いずれにせよ合成ゴム委員会の中では以上のような論 点に立って今日ただ今からこのアルコールからブタジェ ンといら方法で合成ゴム工業を起し，わが國に石油化学 工業が発展した曉にはこれを石油化学工業によるブタジ エンに切り替えればよいという論が起きている。そうす ればその時になるとアルコールからブタジェンの設備が 無䭾になるという心配もないではないが，それまでには 相当の償却をしているし，合成ゴム設備全体から見れば 一部の裝置にしか過ぎないし，またアメリカのように経 済界の変動その他の事由による不時のための予備設備と も考えられるのではないかといらのがそのいい分であ る。事実アメリカでも前述のように今度合成ゴム設備を 民間に拂い下げるに当って，アルコールからブタジェン の設備については今後 10 年間予備設備として民間に保 有させ, 政府の指令によりいっでも操業するという條件 がついている位である。

\section{これに対してかなり强い反対意見がある}

合成ゴム工業は日進月步でこの先どれ程発展するかわ からないからしばらくようすを見た方がよいというのが その一つである。なるほど例えば Goodyear で発明し たといわれるポリエステル樹脂の 1 種である Isocyanate Elastmer すなわちグリコールとアジピン酸のポリェ ステル樹脂に Organic Isocyanate を作用させたものと か, Du Pont の発明だといらポリェチレンのクロールス ルフォン酸誘導体など目新しいものが出ているようだ が, アメリカの諸権威の語るところも，ドイッの各権威 の語るところも，これらが合成ゴムとして廣く用いられ ることは当分あるまいといらことだし，何が出るかわか らぬからようすを見ていてはいつになっても手をつけら
れずなならの進步も見られないことはあらゆる面であ らゆる人が経驗していることである。

アメリカの合成ゴム工業が民間に拂、下げられると今 までは國有であったから各社は自分のところの発明を完 全に提供することはしなかったが，民間事業となるとそ れらの新しい発明がどっと表面に出てきて GR-Sそのも のにも大きな進步が出てくるであろうから，それらがわ かるまでょらすを見るべきだというのがその二つであ る。筆者等はこの危險を防ぐために今度日本で合成゙゙ム 工業を興すにしても日本だけの力ではやらず，先進國 の有力会社の技術提携をした上で行うべきだと考えて いる。筆者等の小さい経驗でいえば契約の仕方によって は，契約期間內の改良発展はお互に通報し合うことがで きて, お互がお互の研究室を自分のものと考えてもよい 位になることができ，そこに大きな力を得，支拂う技術 料の意味も强くなると考えている。

これらにも䏆して强い意見は前に触れたこともあるよ らに日本の石油化学工業の進展を待つという第三の反対 意見である。その表面だけならば前述したように今日た だ今から合成ゴム工業を起して，そういら事態が起きて きたときに切り替えればよく，あるい洽成ゴム工業を 先んじて起すことが石油化学工業の発展を促すことにも なると考えることもできるが，実はこの論の論拠の一番 の强さはアルコールからでは合成ゴムが高くなるという ことである。その計算は前にも略述したところだが，こ れは実は外貨がいかに大切であるかということに思いを 致すならば自ら明らかなことであろらと思うがどうであ ろらか。

以上のように合成ゴム委員会の中ではいわゆる時期厼 早論がかなり强く出ていてその結論を導き出せない狀態 にあるようだが，委員会の內外を問わず，ぞこにも合成 ゴム工業を起すことについての反対論は出ていないの で，おそらく日本に合成ゴム工業の起ることは目近のこ とと思われる。(つづく)

(山陽化学常務・協和酸唒孝取締役・工博)

\section{研究論文集}

[基礎工学]

[14] 合成樹脂ラテックスの磼用记関する研究

\section{[化学]}

[15 16] 乳化剤共存下の乳化重合

第8 報アクリル酸メチルの乳化重合

[17] ビニル第 9 報 メタクリル酸メチルの乳化重合
本誌は高分子物理ならびに化学 の論文を揭載いたして扣ります 扒申达みの方は本会事務局心。

藤井光雄・大冢保治 .岡村誠三・本山卓彥

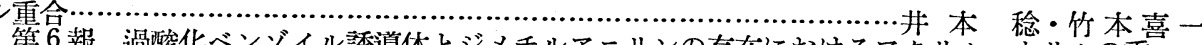
合につマて

[18] 合成高分子化合物の溶解熱.

第 3 報 ポリビニルアルコールの部分酶酸化物の溶解熱 .相 宅 省 吾

[19] 尿素樹脂の潜伏性硬化剈としてのアミノスルホン酸の触媒作筩に関する研究……秋田 務・長井登之雄

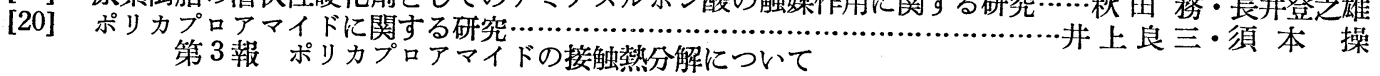

